\title{
The Aftermath of Aum Shinrikyo: A New Paradigm for Terror?
}

\author{
Marie Isabelle Chevrier University of Texas at Dallas, USA
}

I can remember exactly where I was when I learned that nerve gas had been released in the Tokyo subway, just as I recall my whereabouts for other catastrophic events, such as the Oklahoma. City bombing or the Challenger disaster. My initial reaction was disbelief: "It can't be nerve gas," I thought, "not enough people are dead." Only later did I learn that the nerve gas was diluted, of poor quality, and incffectively dispersed, all of which contributed to the relatively low number of fatalities. Jonathan Tucker brings us a vivid account of the subway attack and Aum Shinrikyo, the group which planned and carried out the event. In contrast to other recent articles conjuring horrific visions of chemical or biological terrorism (Wright, 1995; Taylor, 1996), Tucker is careful to avoid sensationalism and is appropriately measured in his predictions. Moreover, Tucker is to be lauded for his cool-headed effort to analyze the nature of Aum Shinrikyo and other groups that may be candidates for infamy.

One of Tucker's principal arguments is that we face an increased likelihood of chemical and biological terrorism from groups like Aum Shinrikyo, which, according to Tucker, is a "new type of terrorist organization, combining elements of a doomsday cult and a large-scale criminal enterprise." Furthermore, he argues that "terrorists motivated by religious or racist fanaticism are particularly dangerous because, unlike politically motivated groups, they are not subject to rational constraints on the scope of their violent acts..." (emphasis added).

This line of argument has several troublesome aspects. First, nearly all definitions of terrorism include political motivation as an essential characteristic (see, e.g., Jenkins, 1980:2-3; Provizer, 1987; Stcrn, 1993:393). What consequences and policy implications flow from expanding ter-

Marie Isabelle Chevrier is Assistant Professor of Political Economy at the School of Social Sciences, GR-31, University of Texas at Dallas, Box 830688, Richardson, TX 75080-(0688, USA (E-mail: CHEVRIER@UTDALLAS.EDU). Dr. Chevrier, who holds a Ph.D. in public policy from Harvard University, is a member of the Federation of American Scientists Working Group on Biological and Toxin Weapons Verification and the principal author of the group's report: "Beyond VEREX: A Legally Binding Compliance Regime for the Biological and Toxin Weapons Convention." She is working on a book on the role of the nonaligned countries in arms control negotiations. rorism's definition to include motivations other than political? Second, Tucker's distinctions between politically motivated terrorists and others-the more dangerous kind-seems strained. It appears evident that Aum's goal - to assume "supreme power in Japan"-is inherently political, as was Aum's attempt to assassinate three judges using nerve gas. Beyond the question of Aum's political motivation or lack thereof, the categories of "political terrorist" and "terrorist motivated by religious or racist fanaticism" are not mutually exclusive. Many terrorist organizations combine religious fervor with their politics. Into which category, for instance, do we put Hamas? Indeed, Tucker's list of chemical and biological (C/B) "incidents" includes those involving political groups and political motivations.

Third, to assert that religious or racist fanatics "are not subject to rational constraints on the scope of their violent acts" is to admit defeat before we even attempt to analyze such organizations and the rational constraints to which they might respond. It is too easy to dismiss a group or organization as irrational. It absolves us of responsibility to try to understand and respond to a line of reasoning that is perhaps antithetical to our own. Wouldn't a group interested in expansion consider the effect of large-scale violence on its ability to attract followers, especially those individuals with the technological knowledge and skills to carry out sophisticated $\mathrm{C} / \mathrm{B}$ scenarios? Wouldn't a group worry that $\mathrm{C} / \mathrm{B}$ terrorism would inevitably intensify the target government's motivation to destroy it?

Indeed, one could examine the aftermath of the Tokyo subway attack and reach widely divergent conclusions concerning its effect on other groups considering $\mathrm{C} / \mathrm{B}$ terrorism. Many analysts conclude that a strong taboo against chemical terrorism, and by extension biological terrorism, was broken. Once the taboo has been broken, the theory goes, more $\mathrm{C} / \mathrm{B}$ incidents and more deadly incidents are sure to follow. A second inference is that technological difficulties, including those encountered by Aum that limited the number of fatalities, could reasonably be overcome.

On the other hand, one could look at Aum's experience in an entirely different light. Aum Shinrikyo, with over a billion dollars in assets and the ability to recruit scientists and purchase sophisticated equipment, did not plan and carry out an attack that produced massive fatalities. Perhaps

Acknowledgments. The author wishes to thank Paul A. Jargowsky and Roxanne Lieb for their assistance and constructive comments. 
Aum did not want to kill in large numbers, but to shock in large numbers. Perhaps the technical hurdles, which Tucker concludes are still substantial, continue to be a binding constraint, especially for biological terrorism. While Stern states that the risk of failure for a terrorist group is "minimal" (1993:402), the empirical record is marked by many incidents of failure. Furthermore, there may be many more failures that we have never heard of; whereas, there are no hidden successes, at least in terms of CW attacks or those with large numbers of casualties.

Similarly, I question whether the willingness of members of some messianic religious cults to commit mass suicide is necessarily evidence that the members of such groups are willing to turn their destructiveness outward. The connection between the two types of violence-suicidal and homocidal-seems tenuous at best. Moreover, suicide, even on a massive scale, can generally be carried out more quickly, or impulsively, than a complicated plan to kill a large number of people using chemical or biological weapons (CBW). The time and effort involved in planning and executing a CBW attack would usually allow much greater opportunity for reflection and development of reservations than mass suicide.

Tucker reports that in addition to mail-order access, "deadly cookbooks are also available on the Internet." However, the ease with which a terrorist could download a foolproof recipe for $\mathrm{C} / \mathrm{B}$ weapons from the World Wide Web may be exaggerated. An afternoon surfing the Net yielded the following: the table of contents of The Anarchist's Cookbook and The Terrorists' Handbook, but not the actual texts; The Jolly Roger Cookbook, which was filled with instructions on how to construct all sorts of explosives, but nothing resembling even World War I vintage chemical weapons; and several sites whose titles resembled, but were not identical to, those cited by Tucker. A number of the sites that Tucker mentions, including one with "a recipe for the home production of botulinum toxin," were either gone from the Net or not available using several search engines. The nature of the Internet is that information available yesterday may be gone tomorrow and vice versa. In spite of the widespread repugnance triggered by the availability of this type of information-including the presumably more reliable instructions for explosives-it seems unlikely that any group that could obtain the equipment and personnel skilled in carrying out a $\mathrm{C} / \mathrm{B}$ attack would rely on the Internet for accurate instructions on production or dispersal of the weapons. A site containing frequently asked questions about The Anarchist's Cookbook noted that it contained numerous factual errors, including the chemical formula for alcohol.

Tucker's agenda of short- and long-term policy prescriptions is thorough and well argued. A number of his recommendations to prevent future CBW terrorist incidents mirror those of Stern (1993:406-410) and Kupperman and Smith (1993:43-46), including the directives concerning ratification and entry into force of the CWC, imposing civil liability on those who provide information on $\mathrm{CBW}$ production, augmenting the existing intelligence effort, and creating a $\mathrm{C} / \mathrm{B}$ equivalent of the Nuclear Emergency Search Teams. Tucker, however, includes needed detail and additional measures. Tucker also provides well-reasoned advice on how to prepare for a C/B attack should one occur. Notably absent from Tucker's recommendations is any mention of the Biological Weapons Convention (BWC) and current international efforts to strengthen compliance with its provisions (Chevrier, 1995).

A robust regime to increase transparency of biological research and development and to create disincentives for the governmental production of biological weapons (BW) could go a long way toward decreasing the likelihood of statesponsored BW terrorism and could also augment any national means to detect and deter other terrorist groups. Making the possession of BW a crime under international law could facilitate the prosecution of those who possess deadly pathogens or toxins and the means to deliver them (Meselson and Perry Robinson, 1996).

The prospect of terrorist groups or individuals using chemical or biological weapons - whether or not great numbers of fatalities ensue-is indeed dire. Yet predicting the future, particularly when those predictions involve low probability events, is fraught with uncertainty. Additionally, analysts would certainly rather predict or suggest that ominous events will happen, and be proven wrong, than to be circumspect about the likelihood of disaster and be similarly proven wrong. The consequences of error are much more serious in the latter case than in the former. Consequently, we see a proliferation of "worst case scenario" planning and repeatedly hear the adage, "plan for the worst; hope for the best."

With the prevalence of this type of thinking, it is not surprising that the release of a liquid containing a nerve gas by the Aum Shinrikyo group in Tokyo has prompted Tucker, as well as other, less scholarly, writers to conclude that we are facing a new threat-that of chemical/biological terrorism. Their predictions - that some terrorist groups will increasingly turn to $\mathrm{CBW}$ - are not new and are generally based on rather scant empirical evidence (Douglass and Livingstone, 1987; Simon, 1989; Root-Bernstein, 1991). Indeed, Tucker's list of four criteria that could help predict which terrorist groups might turn to $\mathrm{C} / \mathrm{B}$ weapons is strikingly similar to a list developed by Simon seven years ago (1989:17).

One argument frequently made is that the public has become inured to terrorists' use of explosives and a terrorist group can no longer fixate the public's attention on its activities with conventional means. Yet the bombing of the Federal Office Building in Oklahoma City demonstrates how effective, and visually riveting, relatively simple explosive devices can be. Perhaps one of the unintended but nevertheless welcome consequences of that bombing is that terrorists need not turn to $\mathrm{C} / \mathrm{B}$ weapons to command the public's undivided attention or to produce high casualties. 


\section{References}

Chevrier, M.I. (1995). "From Verification to Strengthening Compliance: Prospects and Challenges of the Biological Weapons Convention." Politics and the Life Sciences 14:209-19.

Douglass, J.D.J. and N.C. Livingstone (1987). America The Vulnerable: The Threat of Chemical/Biological Warfare. Lexington, MA: Lexington Books.

Jenkins, B.M. (1980). Terrorism in the 1980's. Santa Monica, CA: RAND P-6564 (December).

Kupperman, R.H. and D.M. Smith (1993). "Coping with Biological Terrorism." In B. Roberts (ed.), Biological Weapons: Weapons of the Future? Washington, DC: The Center for Strategic and International Studies.
Meselson, M.S. and J. Perry Robinson (1996). "Criminalizing BW." Chemical Weapons Convention Bulletin No. 31 (March): 1.

Provizer, N.W. (1987). "Defining Terrorism." In M. Slann and B. Schechterman (eds.), Multidimensional Terrorism. Boulder, CO: Lynne Rienner.

Root-Bernstein, R.S. (1991). "Infectious Terrorism." The Attantic 267 (May):44, 48-50.

Simon, J.D. (1989). Terrorists and the Potential Use of Biological Weapons: A Discussion of Possibilities [Prepared for the U.S. Armed Forces Medical Intelligence Center]. Santa Monica, CA: RAND R-3771-AFMIC.

Stern, J.E. (1993). "Will Terrorists Turn to Poison?" Orbis (Summer):393-410.

Taylor, R. (1996). "All Fall Down." New Scientist (May 11):32-37.

Wright, R. (1995). "Be Very Afraid." The New Republic (May 1):19-27.

\title{
Countering Chem-Bio Terrorism: Limited Possibilities
}

\author{
Leonard A. Cole Rutgers University—Newark, USA
}

$\mathbf{J}$ onathan Tucker has written a timely, thoughtful, and provocative article about chemical and biological terrorism. Provocative? What could be controversial about wanting to protect people from a terrorist attack? Nothing, if a protective program were practical and likely to be effective. And therein lie questions about some of his proposals.

Tucker presents a credible description of chemical and biological weapons. He explains how they can be used, the kind of terrorist that might wish to use them, and he proposes possible countermeasures. He notes that the 1995 sarin attack in the Tokyo subways by Aum Shinrikyo weakened a taboo against the use of these weapons in terrorist attacks. Thus, he calls $\mathrm{C} / \mathrm{B}$ terrorism an "emerging threat." Nevertheless, he concludes (somewhat incongruously) that another large chemical or biological terrorist attack is unlikely.

Leonard A. Cole is a political scientist at Rutgers University, Newark, NJ, where he serves as faculty associate in the Program in Science, Technology, and Society. His research interests are in the area of science and public policy, including biological and chemical warfare issues, about which he has written extensively. $\mathrm{He}$ has been a visiting research scholar at the University of Helsinki, and in 1996 was a Rockefeller Foundation Scholar-in-Residence in Bellagio, Italy, where he finished his most recent book, The Eleventh Plague: The Politics of Biological and Chemical Warfare (W. H. Freeman, 1996). Cole's previous books include Element of Risk: The Politics of Radon (Oxford University Press, 1994) and Clouds of Secrecy: The Army's Serm Warfare Tests Over Populated Areas (Rowman and Littlefield, 1988). Correspondence should be addressed to 381 Crest Road, Ridgewood, NJ 07450, USA.
No one can be sure what the chances of another attack are. Nor can Tucker or anyone else know whether his proposed countermeasures would substantially enhance prevention or protection. Some seem likely to help, but others to cause more problems than benefits.

Tucker offers 14 proposals (seven short-term, seven long-term) to address the threat. Especially appealing are his suggestions for prevention, such as implementing the Chemical Weapons Convention, enhancing intelligence efforts to forestall attacks, and encouraging global epidemiological surveillance programs.

But his civil defense proposals are less plausible. In particular, benefits from stockpiling chemical and biological defense materials at major medical centers are likely to be illusory. The materials presumably would be available for use in an unexpected attack. A limited number of victims who receive quick treatment might be helped, but most of the materials could never be used effectively.

If a purified nerve agent were to be released in a subway system (the sarin used in the Tokyo attack was impure), thousands of people could be dead in minutes. Therapy for even moderate nerve gas exposure must begin within a minute or two, or it is useless (SIPRI, 1973:59, 107). Antidotes like atropine stored at medical centers could not be administered in time.

In a biological attack, the consequences could be more devastating. Because of their stability and virulence, anthrax spores are regarded as a likely biological weapon. An anthrax attack might produce casualties numbering hundreds of thousands (Kupperman and Smith, 1993). Moreover, as Tucker notes, unless vaccinated against, anthrax cannot be cured by antibiotics; they can only delay progress of the 